\title{
TIEDÄN, USKON JA USKALLAN
}

\section{ANTTI ESKOLA (2003) Tie- dän ja uskon. Otava.}

Luin muutama vuosi sitten hyvin kiinnostuneena Antti Eskolan kirjan "Uskon tunnustelua - mitä Jumalasta pitäisi ajatella?". Pidin kirjasta ja sen tietystä hapuilevasta luonnosmaisuudesta erittäin paljon. Kirjan lukemisen jälkeen minusta tuntui siltä, kuin aurinko olisi pais-tanut aiempaa kirkkaammin. Niinpä tartuin innostuneena myös Eskolan uudempaan teokseen "Tiedän ja uskon".

Uusi kirja oli mielestäni raskaampi ja vaikeammin käyntiin lähtevä kuin edeltäjänsä. Se oli hieman kuin sellainen hämärä ja pilvinen päivä, joka ei aluksi innosta oikein mihinkään, mutta joka kuitenkin loppujen lopuksi päättyy mukavaan iltaan. Vaikka aurinko ei alkanutkaan paistaa, loppuarvioni on se, että "Tiedän ja uskon" kannatti kaikesta huolimatta lukea.

Monien mielestä Eskolan uskon tunnusteluissa on ollut kiehtovinta se, että aikanaan hyvin vasemmistolaisena tunnettu tiedemies kaikesta huolimatta kääntyy uskonnon pariin - ikään kuin sekä vasemmistolainen maailmankatsomus että kyky ajatella tieteellisesti olisivat jotenkin automaattisesti vastakkaisia sille, että ihminen tuntee tarvetta pohtia myös elämän mielekkyyttä, armon merkitystä ja sitä, mitä kristillinen usko kenties on tai ei ole. Itse en ajattele niin. Minun sukupolveni maailmassa useammanlaiset asiat ovat jo voineet elää ja kukoistaa rauhassa vierekkäin, jopa saman ihmisen elämässä - olenhan itsekin yh-teiskuntatieteellisen tutkijakoulutuksen saanut ortodoksiseen kirkkoon kuuluva vasemmistolainen henkilö. Pidän siitä huolimatta kiehtovana sitä, mitä Eskola pohdiskelee ja miten.

\section{RAJASEUTU-ANALOGIA ON PUHUTTELEVA}

Sekä ikään että yhteiskuntatieteiden kehittymiseen liittyy selviä sukupolvieroja. Niiden vaikutus näkyy mielestäni vahvasti siinä, miten tärkeänä Eskola (s. 1934) pitää positivisti-sesti määritellyn tieteellisen maailmankuvan edes jonkin-laista yhteensovittamista muun-laisten havainnointi- ja käsitteellistämistapojen kanssa. Omalle sukupolvelleni (s. 1963) tieteellinen maailman-kuva ei ole enää ollut yhtä ahdas. Siihen on tullut sävyjä paljon positivismia enemmän, ja siksi kirjan korostama "tiedollisuus" tuntui minusta hetkittäin jopa häiritsevältä. Tästä sukupolvierosta huolimatta Eskolan analogia rajaseudusta ja siitä, mitä kaikkea voi tulla vastaan, kun kaupunki jää taakse, on mielestäni puhutteleva. Tällaisia rajaseutuja on paljon muuallakin kuin ankaran tieteellisen maailmankuvan muodostamien kaupunkiseutujen ulkopuolella.

Eskola kuvaa pohdintojaan erilaisten vaihduntakuvioiden, teologisten sitaattien ja yh-teiskuntatieteen metodien avulla ja tavoittelee sen avulla jonkinlaista ymmärrystä ja hyväksyntää sille, että asioita ja ilmiöitä voi nähdä monin eri tavoin. Tuo samainen ymmärtämisen pyrkimys on mielestäni myös Esko- lan ansaitusti peräänkuuluttaman näkemisen rikkauden ja siihen liittyvän sallivuuden takana. Mutta jos olisin itse saanut antaa Eskolan kirjalle nimen, se ei kuitenkaan olisi ollut "Tiedän ja uskon - ja ymmärrän" vaan "Tiedän ja uskon - ja uskallan". Vaikka uskonnollinen pohdinta varmasti hakeekin jonkinlaista ymmärrystä, itse uskominen lie-nee sittenkin syvimmillään nimenomaan uskaltamista - aivan niin kuin on rakastaminenkin, josta Eskola puhuu vähemmän, mutta johon hän kuitenkin onneksi kirjan loppupuolella viittaa.

Jokainen lukee kirjoja omalla tavallaan ja se pätee tietysti myös minuun ja Eskolan kirjaan. Itseäni puhutteli eniten nimenomaan kirjan loppu, se viimeinen rajaseutu, jossa kirjoittajan pohdinta karisti yltään liki kaiken metodisen taakan ja muuttui vain hyvin henkilökohtaiseksi. Kirjan lopussa vilahtaa myös rakkaus - se kaikki, minkä ihminen sai, kun hän uskalsi kaikesta huolimatta sittenkin rakastua, perustaa perheen ja elää yhdessä toisen ihmisen kanssa; valinta, jonka Eskola rinnasti mielestäni hienosti uskomaan uskaltamisen kanssa.

\section{TARVITAAN VAIN KIITOS JA KIITOLLISUUS}

Niin vähän on tarpeen: usko ja uskallus, merkityksen anto ja rakkaus. Mieleeni jäi rakkauden lisäksi vahvasti myös se, miten vähän rukoukseen Eskolan mielestä tarvitaan: kiitos ja kiitollisuus kaikesta siitä, mitä on. Ja kuitenkin siinä on miltei kaikki. Itse liittäisin kiitoksen rin- 
nalle vielä armon, en armoa jo annettuna asiana (vaikka se onkin kristillisyyden ydin), vaan vasta pyydettynä ja anottuna, sellaisena, joka ei ole tarpeen vain jokaiselle yksilönä vaan koko ihmiskunnalle, kaikille meistä meidän pahojen tekojemme loputtoman suuren määrän tähden. Syntien määrän miettiminen on tässä maailmassa harvinaista, ja siksi on hie- noa, että Eskola tekee myös sitä.

Kirjan loppuosassa näkyi myös se rakkaus ja hyväksyntä, joka oli kaiken alussa, siis Eskolan lapsuuden kodissa ja Eskolan ja hänen sisarustensa suhteissa. Lapsuuden valo - jos sitä on ollut - on kai sittenkin se, mikä viime kädessä valaisee ihmistä hänen puuhissaan tai sitten on valaisematta. Kun kirjan saa loppuun, käteen jää mie- lestäni juuri tuo ihmeellinen ja ihana lapsuuden valo - ja kiitollisuus siitä, että sellaista valoa on ollut ja on niin Eskolan kuin monen muunkin ihmisen elämässä. Ilman sitä maailma olisi paljon synkempi ja pimeämpi paikka.

Suvi-Anne Siimes 